\title{
PENYEBAB TERJADINYA PEMOGOKAN KERJA
}

\author{
Oleh: \\ Muhammad Ayub ${ }^{1}$, Arda Alvin Pandu Eka Putra ${ }^{2}$, Oci Senjaya ${ }^{3}$ \\ ${ }_{1,2,3}^{3}$ Universitas Singaperbangsa Karawang \\ 19yubm6573@gmail.com; ${ }^{2}$ ardaalvinpandu@gmail.com; ${ }^{3}$ ocisenjaya90@gmail.com
}

\begin{abstract}
ABSTRAK: Tenaga kerja merupakan orang-orang yang bekerja di perusahaan, perkantoran, pabrik, dan lain-lain. Tenaga kerja atau karyawan merupakan profesi pekerjaan yang biasa bekerja di suatu instasi yaitu perusahaan swasta maupun negeri. Pemogokan kerja kadang dilakukan oleh sebagian tenaga kerja yaitu sebagai guna menyampaikan aspirasai terhadap perusahaan. di Indonesia sendiri masih bayak terjadi karena kurangnya komunikasi antara pekerja/buruh kepada organisasi pengusaha. Namun banyaknya pemogokan kerja ini masih saja terjadi, ini membuktikan bahwa banyaknya pekerja/buruh kita masih kurang mendapatkan upah yang layak dan hak-hak merka yang belum terpenuhi. Karena itu masih banyaknya pemogokan kerja yang terjadi, nanmun tidak hanya dari faktor pendorong upah yang kurang layak, faktor dari adanya pekerja/buruh sendiri juga menjadi faktor pendorongnya pemogokan kerja. Dengan melakukan pemogokan dari pekerja/buruh ini agar merka dapat mendapatkan perhatian dari pihak perusahaan agar dapat didengar aspirasinya untuk berkeingin diberikan upah yang layak dan tunjangan hidup yang layak.
\end{abstract}

\section{KATA KUNCI: Buruh, Pemogokan, Upah}

ABSTRACT: Workers are people who work in companies, offices, factories, and others. Manpower or employees are occupations that usually work in an agency, namely private and public companies. Work strikes are sometimes carried out by some workers, namely as a means of conveying their aspirations to the company. In Indonesia, there are still many incidents due to lack of communication between workers/laborers and employers' organizations. However, the number of work strikes continues, this proves that there are still many of our workers/laborers who have not received adequate wages and their rights have not been fulfilled. Therefore, there are still many work strikes that occur, but not only from the insufficient wage driving factor, the factor of the presence of workers/ laborers itself is also a driving factor for the occurrence of these strikes. By carrying out a strike action against workers/laborers, in order to get the company's attention so that their aspirations are heard to be given a decent wage and decent living allowance.

KEYWORDS : Labor, Strikes, Wages

\section{PENDAHULUAN}

Pekerja/buruh merupakan tenaga kerja yang diperlukan setiap orang untuk bisa melakukan pekerjaan yang dapat menghasilkan sesuatu seperti barang atau jasa yang dihasilkan dari pekerjaannya.
Pekerjaan yang dilakukan oleh tenaga kerja merupakan pekerjaan guna untuk memenuhi segala kebutuhan baik untuk diri sendiri maupun untuk masyarakat 
banyak. ${ }^{1}$ Menurut ketentuan UU No. 13 Tahun 2003 tentang ketenagakerjaan beserta peraturan pelaksanaannya, dari setiap peraturan pemerintah, peraturan menteri, hingga keputusan-keputusan menteri yang terkait dalam ketenagakerjaan, dapat ditarik suatu kesimpulan bahwa adanya beberapa pengertian dari ketenagakerjaan, sebagai berikut:

1. Ketenagakerjaan merupkan segala sesuatu yang berhubungan terhadap tenaga kerja pada waktu sebelum mendaftar diri sampai selesainnya masa kontrak atau hubungan pekerjaannya.

2. Tenaga kerja merupakan suatu objek yang sangat dibutuhkan dalam kehidupan sehari-hari, yaitu dari setiap orang yang melakukan pekerjaan mampu untuk menghasilkan barang atau jasa, untuk kebutuhan sendiri dan orang lain.

3. Pekerja atau buruh yaitu orang yang bekerja untuk orang lain dengan menghasilkan jasa atau barang, dari hasil tersebut menerima bayaran bisa berupa uang atau imbalan dalam bentuk lain.

4. Pemberi kerja adalah suatu orang perseorangan atau badan hukum yang memberikan pekerjaan atau memperkejakan orang lain untuk keperluan orang atau badan huku dengan diberi imbalan berupa membayar upah atau imbalan dalam bentuk lain. $^{2}$

Di dalam dunia pekerjaan pasti memiliki beberapa masalah, masalah ketenagakerjaan di masa datang akan terus terus berkembang hingga semakin

\footnotetext{
1 Muhammad Azhar, Hukum Ketenagakerjaan, (Semarang: Buku Ajar, 2015), hal. 8.

2 Whimbo Pitoyo, Panduan Praktis Hukum Ketenagakerjaan, (Jakarta: Transmedia Pustaka, 2010), hal. 3.
}

kompleks sehingga memerlukan penanganan yang lebih serius. Pada perkembangan masa tersebut pergeseran nilai dan tata kehidupan akan banyak terjadi. $^{3}$

Pemogakan kerja merupakan salah satunya masalah yang kerap terjadi di Indonesia. Pemogokan kerja yang dilakukan oleh pekerja/buruh dikarenakan mereka merasa adanya ketidak adilan terhadap pekerja/buruh. Dalam permasalahan tersebut pekerja/buruh kerap sekali melakukan unjuk rasa berupa pemogokan kerja terhadap perusahaan dan pemerintah dikarenakan mereka meminta keadilan yang setara untuk pekerja dengan perusahaan. Sehingga tidaka ada lagi kesenjangan terhadap pekerja/buruh dengan perusahaan.

Pemogokan kerja di Indonesia sampai saat ini dikarenakan akibat tidak harmonisnya hubungan antara pekerja dan pengusaha, akibat dari kondisi itu ikut berdampak pada perekonomian nasional. Demikian dikemukakan oleh staf ahli Menteri Ketenagakerjaan Ruslan Irianto dalam disertasinya yang berjudul "Pola Hubungan Industrial Pada PT Toyota Motor Manufacturing Indonesia, Tbk Jakarta". ${ }^{4}$

Faktor penyebab pemogokan kerja dilakukan lantaran pekerja/buruh merasa upah yang diberikan tidak sesuai dengan kinerja yang dihasilkan, sehingga memicu adanya tindak proses pekerja/buruh terhadap perusahaan dan pemerintah agar diberikan upah yang sesuai dengan kinerja yang diberikan tenaga kerja. Berdasarkan dari kebijakan Undang-Undang Ketenagakerjaan

3 Undang-Undang RI Nomor 2 Tahun 2003 tentang pengawasan ketenagakerjaan di indonesia, hal. 7

${ }^{4}$ Muhammad Ayub, "Pemogokan Terjadi Akibat Hubungan Kerja Tak Harmonis", https://kabar24.bisnis.com/, (diakses pada tanggal 8 april 2021, 13:05) 
diberlakukan untuk menjamin kesejahteraan karyawan di tempat kerja. Pda pasala 88 Ayat (1) Undang-Undang Ketenagakerjaan No. 13 Tahun 2013. Menyatakan bahwa setiap karyawan/pekerja/buruh berhak memperoleh penghasilan unruk memenuhi kebutuhan hidup mereka secara layak dari segi kemanusiaan. ${ }^{5}$

Sejarah awal mula terjadinya pemogokan kerja yang terjadi di Indonesia yaitu terjadi pada jaman penjajahan kolonial Belanda pada tahun 1897 dengan nama Nederlandsch Indisch Onderwijzer Genootschap yang disingkat (NIOG), yang dipelopori gerakan sosial yang dilakukan oleh kaum pendidik. ${ }^{6}$ Diawali dengan adanya gerakan tersebut masyarakat memberanikan diri untuk menuntut keadilan dan hak-hak yang harus diberikan terhadap pekerja/buruh.

Pekerja/buruh bukan merupakan seorang budak melainkan tenaga kerja bantuan yang dibutuhkan oleh orangperseorangan atau badan hukum dalam membantu pekerjaan. Oleh karena pekerja/buruh harus diberikan imbalan yang sesuai dengan hasil kinerja yang mereka keluarkan. Mayoritas penduduk di Indonesia merupakan agama Islam apabila ekonomi Islam dijadikan cerminan untuk mengatasi masalah buruh di Indonesia, maka kita dapat menemukan pantulan angka yang ganjil. Set up buruh sebagai bagian dari sistem produksi dengan metafora mesin. Upah yang harus diberikan kepada buruh dianggap sebagai cost (biaya) yang kongruen dengan hasil produktivitas yang dikeluarkan, tanpa pernah melirik nilai islamseharusnya dapat menjadi bagian dari sistem kesadarnnya. Oleh karena itu upah buruh yang diberikan tak heran

\footnotetext{
${ }^{5}$ Undang-Undang Ketengakerjaan Pasal 88 Ayat (1) Nomor 13 tahun 2013

6 Sigit Rochadi, Gerakan Buruh Indonesia Perlawana dan Fragmentasi, (Jakarta: Bumi Aksara, 2020), hal. 1.
}

sangat rendah diberikan oleh pengusaha lantaran menurut pengusaha sangat menguntungkan untuk perusahaan. Sebaliknya upah yang terus meningkat menjadi tidak sukai oleh pengusaha dikarenakan menjadi mgurangi laba perusahaan. Akibat dari dari ulah pengusaha yang lebih mengutamakan keuntungan yang berlebihan, dapat menimbulkan resiko unjuk rasa berupa pemogokan yang dilakukan oleh pekerja/buruh. Sehingga dapat juga menjadi dampak negatif untuk perusahaan yang dapat menyebabkan kebangkrutan. Oleh karena itu diperlukannya tarik menarik kepentingan antara kaum buruh dan perusahaan agar adanya keseimbangan dan keadilan yang sama rata antara pekerja dan perusahaan. ${ }^{7}$

Banyaknya proses pembangunan dan moderenisasi di Indonesia yang dilakukan oleh pemerintah melalui aktifitas yang berputar dan berunjung industrialisai. Menjadi faktor tingginya pilihan masyarakat untuk bekerja menjadi buruh pabrik pada akhirnya, di karenakan mencari aman untuk memenuhi kebutuhan hidup. Namum dari pemikiran tersebut menyebabkan banyaknya terjadinya penumpukan masyarakat atau urbanisasi. Dikarenakan faktor gerakan tersebut memberikan banyak harapan bagi masyarakat untuk bisa memenuhi masyarakat untuk kebutuhan hidup mereka. Banyaknya industri yang memberikan kemudahan-kemudahan itu menjadi daya tarik tersendiri untuk masyarakat sehingga membuat tertarik dalam prosesnya. Mereka memberikan kesesuaian dengan tingkat keterampilannya masing-masing, karena itu menjadi terdorong untuk menjadi

\footnotetext{
7 Abdul Jalil, Teologi Buruh, (Yogyakarta: Lkis Yoyakarta, 2008), hal. 5.
} 
bagian proses itu, dengan tujuan untuk memenuhi kebutuhan hidup. ${ }^{8}$

Dalam Undang-Undang N0. 13 Tahun 2013 tentang ketenagakerjaan bahwa pengusaha bertanggung jawab atas peningkatan dan atau pengembangan kompetensi pekerjaan melalui pelatihan kerja. Peningkatan dan atau pengenbangan kompetensi sebagaimana dimaksud dalam ayat (1) diwajibkan bagi pengusaha yang memenuhi persyaratan yang diatur dengan keputusan Menteri. Setiap pekerja/buruh memiliki kesempatan yang sama untuk mengikuti pelatihan kerja sesuai dengan bidang tugasnya. $^{9}$

\section{METODE}

Metode yang di pergunakan dalam penelitian ini yaitu metode penelitian deskritif. Metode ini mengumpulkan data secara detail, mendalam dan juga actual. Di dalam sebuah penelitian biasanya akan di jelaskan mengenai gejala-gejala yang sudah ada misalnya tentang masalah serta meneliti kondisi yang tetap berlaku. Penelitian ini juga menjadikan perbandingan tentang apa yang bisa di lakukan untuk menentukan sebuah solusi dalam menghadapi sebuah permasalahan.

Sehingga di saat memakai metode penelitian ini, maka artinya penelitian mempunyai sebuah tujuan penelitian untuk bisa menggambarkan secara sistematis dari suatu fakta khusus secara teliti dan juga actual. Selain itu, metode ini bukan sekedar memaparkan analisan tetapi juga di padukan dengan klasifikasi serta organisasi.

Bisa disimpulkan jika penelitian deskriptif ini adalah sebuah metode penelitian yang mencari dan menentukan sebuah ilmu pengetahuan yang mana sesuai dengan penemuan yang sesuai fakta di

\footnotetext{
8 Imam Bawani, DKK, (Yogyakarta: LKIS Yogyakarta, 2011), hal. 1.

9 Undang-undang Ketenagakerjaan No.13 tahun 2003 Pasal 137 (Republik Indonesia, 1990)
}

lapangan. Sehingga pada saat praktiknya, metode ini akan jauh lebih menekan pada observasi lapangan dalam kondisi yang alami.

\section{HASIL DAN PEMBAHASAN}

Mogok kerja yang biasa dilakukan oleh pekerja merupakan suatu upaya para pekerja untuk menyuarakan aspirasinya untuk menunjukan aksi protesnya terhadap atasan, atau perusahaan akan ketidak adilannya hak-hak yang dibeikan kepada tenaga kerja. Tindakan tersebut dilakukan dikarenakan faktor-faktor kurangnya hak-hak yang sebagaimana mestinya harus diberikan terhadap pekerja/buruh karena tidak sesuai dengan hasil kinerja yang sudah dikeluarkan untuk perusahaan atau badan hukum. Faktor lainnya bisa berupa tidak digubrisnya atau tanggapan yang sudah diberikan oleh pekerja/buruh terhadap perusahaan atau badan hukum berupa aspirasi karyawan untuk perusahaan. Dengan kata lain adanya ketidakpuasan terhadap kebijakan-kebijakan yang ada di perusahaan. ${ }^{10}$

Namun dari segala tindakan pemogokan tersebut tidak dibenarkan juga untuk selalu mengutamakan tindakan mogok kerja apabila pekerja mersa dirugikan oleh perusahaan atau badan hukum. Dari hal tersebut alangkah sebaiknya para pekerja tidak asal mogok kerja apabila ingin mengutarakan aspirasinya melainkan dapat juga dengan cara bernegosiasi terlebih dahulu terhadap atasan atau perusahaan dengan cara adanya perwakilan dari salah satu pihak sehingga dapat mengambil jalan tengah yang diperoleh melalui musyawah. Dengan cara diwakilkan tersebut yang dilakukan oleh salah satu

10 Muhammad Ayub "Mogok Kerja", https://www.woke.id/mogok-kerjal, (diakses pada tanggal 20 maret 2018, 23:00) 
pihak dari tenaga kerja dengan pihak perusahaan dapat berdiskusi. Apabila tidak ada jalan tengah secara mufakat tenaga kerja dapat melakukan mogok kerja sebagai salah satu jalan alternatif terakhir. Akan tetapi sebelum melakukan mogok kerja, pekerja harus pahami dan patuhi peraturan yang tertuang dalam Undang-Undang Nomor 13 Tahun 2003 tentang Ketenagakerjaan

(UU Ketenagakerjaan) yang sebagaimna sudah diatur tersebut dan Keputusan Menteri Tenaga Kerja dan Transmigrasi Nomor 232 Tahun 2003. ${ }^{11}$ Sehingga tindakan pemogokan kerja tetap teratur sebagimana mestinya dan tidak menyebabkan huru hara yang dapat menimbulkan kericuhan dan anarkis yang dapat merugikan masyarakat.

Menurut pemikiran Burke gerakan sosial dapat dibedakan orientasinya, yaitu apakan gerakan tersebut untuk memulai suatu proses perubahan atau sekedar reaksi atas suatu perubahan yang sedang terjadi. Dalam kedua kategori itu, gerakan sosial bukan sekedar perilaku kolektif (collective challenge).

Dengan kata lain salah satu cara untuk mengurangi adanya pemogokan kerja pemerintah harus memberikan kebijakan, dengan membuat peraturan baru yang ketetapannya harus mengedepakan keadilan yang sama rata terhadap pekerja dengan perusahaan. Sehingga tindakan pemogokan yang kerap terjadi di lingkungan masyarakat dapat berkurang.

\section{PENUTUP}

Tujuan membuat jurnal ini adalah untuk memberikan pemahaman kepada seluruh masyarakat Indonesia, terutana untuk para pengusaha dan pemerintah. Agar bisa memberikan hak- hak yang layak bagi para pekerja/buruh yang bekerja untuk perusahaan. Karena di negara kita ini masih kurangnya menghargai kinerja pekerja/buruh dan masih menganggap sebelah mata dengan memberikan upah yang tidak sesuai dengan hasil kinerja mereka. Seolah-olah hasil kinerja yang diberikan oleh pekerja/buruh dianggap tidak terlalu berharga.

Dari tindakan tersebut merupakan pemicu adanya timbul unjuk rasa, dengan cara melakukan mogok kerja dikarenakan pekerja/buruh merasa hak-haknya masih kurang terpenuhi oleh perusahaan atau badan hukum. Alangkah baiknya pemerintah harus memberikan solusi dari pemogokan tersebut, sehingga dapat menghilangkan pemogokankerja yang kerap dilakukan oleh pekerja/buruh.

Oleh karena itu saya berharap semoga ke depannya negara kita tidak lagi adanya pemogokan kerja oleh buruh, dan mendapatkan tunjangan hidup yang layak bagi para pekerja/buruh.

Saran saya semoga kedepannya pemerintah dapat lebih lagi dalam memberikan keadilan untuk masyarakat terutama pekerja/buruh. Agar kesetaraan ekonomin di Indonesia menjadi lebih meningkat dan mengurangi angka kemiskinan yang ada di Indonesia

\section{DAFTAR PUSTAKA}

Muhammad Azhar, Hukum Ketenagakerjaan (Semarang: Buku Ajar, 2015), hal. 8.

Whimbo Pitoyo, Panduan Praktis Hukum Ketenagakerjaan, (Jakarta: Transmedia Pustaka, 2010), hal. 3.

Dalinama Telaumbanua, Hukum Ketenagakerjaan, (Jakarta: Deepublish, 2019), hal. 7

\footnotetext{
11 Per Menteri No. 232 Tahun 2003 (Tentang Tenaga Kerja dan Transmigrasi)
} 
Imam Bawani, DKK, (Yogyakarta: Lkis Yogyakarta, 2011), hal. 1.

Abdul Jalil, Teologi Buruh, (Yogyakarta: LKIS Yoyakarta, 2008), hal. 5.

Sigit Rochadi, Gerakan Buruh Indonesia Perlawana dan Fragmentasi, (Jakarta: Bumi Aksara, 2020), hal. 1.

Undang-undang Ketenagakerjaan No.13 tahun 2003 Pasal 137 (Republik Indonesia, 1990)

Undang-Undang Ketengakerjaan Pasal 88 Ayat (1) Nomor 13 tahun 2013.

Peraturan Menteri No. 232 Tahun 2003 (Tentang Tenaga Kerja dan Transmigrasi).

Muhammad Ayub, "Pemogokan Terjadi Akibat Hubungan Kerja Tak Harmonis", https://kabar24.bisnis.com/, (diakses pada tanggal 8 april 2021, 13:05)

Muhammad Ayub "Mogok Kerja" , https://www.woke.id/mogok-

kerjal (diakses pada tanggal 20 maret 2018, 23:00) 